\title{
Reflecting national identity in universal concepts
}

\author{
Larisa Nikolaevna Aleshina ${ }^{1^{*}}$, Irina Aleksandrovna Zaytseva ${ }^{1}$, Evgeniy Sergeevich \\ Smakhtin ${ }^{1}$, Elena Anatolyevna Gilovaya ${ }^{1}$, and Svetlana Sergeevna Lapshina ${ }^{2}$ \\ ${ }^{1}$ Financial University under the Government of the Russian Federation, Department of Foreign \\ Languages and Intercultural Communication, Moscow, Russia \\ ${ }^{2}$ Russian Open Academy of Transport of the Russian University of Transport, Department of \\ Professional Communications, Moscow, Russia
}

\begin{abstract}
The issue of reflecting national mentality in the linguistic worldview continues to be relevant as each people has its own specific mindset and common mood related to moral and ethical features of its formation. The article describes a national concept as a complete combination of thought, religions, cultural traditions, folklore that form a conceptual sphere of a language. Therefore, studying the reflection of national identity in the concepts seems to be essential, as the concept itself is a key category in linguistic research of viewing the world through language. The main purpose of this study is to perform a comparative analysis of conceptual spheres of the Russian and English languages. To achieve this purpose we set several tasks: to characterize peculiarities of expressing the key concepts sovest'/conscience, dobro/good, pravda/truth, krasota/beauty in speech; to identify extralinguistic factors fostering common understanding of the conceptual spheres being analyzed in the Russian and English linguistic worldviews. The article uses a complex research methodology, which combines descriptive and analytical methods, as well as the opposition technique and structural and semantic analysis of a word. The paper concludes that only those connotations of the concepts that become a symbol referring to a certain perspective of national mentality are ethnoculturally essential. In the conceptual spheres of English and Russian, key notions defining value systems of these cultures play a significant role. Evolution of material and spiritual culture is reflected in a concept as a single linguistic unit.
\end{abstract}

Keywords: conceptual sphere, linguistic worldview, mentality, intercultural communication

\section{Introduction}

Comparative analysis of national cultures may be performed through studying mental values represented in certain linguistic worldviews. A notion of national concept as the principal unit of intercultural communication is widely spread and actively implemented in

*Corresponding author: LNAleshina@fa.ru 
the contemporary research society. Nevertheless, there is no unequivocal understanding of this linguistic-cultural phenomenon.

Research objective is to present comparative characteristics of the national identity of cultural context within the conceptual spheres of the Russian and English languages by describing peculiarities of expressing the universal concepts sovest'/conscience, dobro/good, pravda/truth, krasota/beauty in speech and identifying extralinguistic factors fostering the development of significant common traits in the conceptual spheres of both languages.

The nature and various features of mentality, as well as their types and influence, are studied comprehensively nowadays [1-7].

Connection between language and culture is reflected in the conceptual sphere of a language that embodies national identity and spirit and reacts to all changes in various aspects of human activity. National concepts express not only lifestyle characterizing a specific linguistic community, but also a way of thinking formed in the conscience of a linguistic-cultural collective. In the development of linguistic worldview, universal factors, which are the same for the human race, are of great importance. These factors are mechanisms of environmental perception. However, along with common conditions, each people is characterized by its unique culture-specific elements that are typical only for this nation and are ultimately reflected in national mental images constituting a conceptual system of a language. National mental images, which carry a cultural footprint, fully represent historical experience of a nation related to the issues of understanding different elements of nation-specific information that is possessed only by a certain national and cultural collective [8].

The scientific novelty of this paper involves analyzing the most frequent responses to the universal concepts sovest'/conscience, dobro/good, pravda/truth, krasota/beauty.

Being at the heart of communication between native speakers, cultural concepts include values, views, and religious beliefs, time, punctuality, social status, truth, sincerity, and are reflected in the language as an important component of verbal communicative behavior [9].

Studying Russian linguistic worldview, researchers identify key components of linguistic concepts, such as attentive attitude to human relationships, delineation of legality and justice, understanding unpredictability of the world, perception of life as a necessity to mobilize human forces [10].

In the conceptual spheres of English and Russian, we find panhuman concepts, typical for all linguistic worldviews, and unique ones, which are common for a specific national and conceptual world model and add distinctive national and cultural colors to it. The first group includes universal concepts as fundamentals of national mentality. The second one comprises the concepts that are particularly difficult to identify and that characterize connotative realities typical for folk art of separate ethnocultural and linguistic communities. These may be the simplest words, which get connotations in various languages due to different national and cultural factors connected to cultural traditions and folklore.

\section{Methods}

Methodology is complex and is represented by descriptive and analytical methods, as well as the techniques of structural and semantic analysis of a word and the opposition. The main technique used in the paper is the componential analysis of the semantic structure of a word supported by vocabulary definitions; contextual analysis and elements of distributional analysis are implemented as well. 


\section{$3 \quad$ Results}

Mental description of the concepts under consideration is always accompanied by difficulties in the field of cultural linguistics and lexicography, i.e. their denotation is inaccessible for direct observation leading to the necessity of implementing indirect techniques of interpretation.

The study of the notional components of the concepts sovest'/conscience, dobro/good, pravda/truth, krasota/beauty demonstrates the fact that their ethno-cultural features are concentrated in national traditions, folklore and common life views on the nature of human being.

\section{Discussion}

We consider axiological concepts, which are ranked on the top of the hierarchy of philosophical, ethical and psychological concepts, as its main attributes.

Comprehensive investigation of the representation of the concepts sovest'/conscience, dobro/good, pravda/truth, krasota/beauty in the Russian and English linguistic worldviews is presented below.

\subsection{Concept sovest'/conscience}

The concept совесть / conscience is defined as “a person's ability to assess his or her actions, as well as thoughts and feelings, from the perspective of morality, and feel deeply sorry if they do not meet moral norms, therefore alter his or her actions consequently, so that they correspond to these norms" [11]. 'Dictionary of Ethics' defines conscience as "a category of ethics characterized by a person's capability to perform moral self-control, formulate independently for oneself moral obligations, demand of oneself to fulfil these obligations and to carry out self-judgment of committed actions" [12].

In the linguistic worldview, the concept represents a specific moral and psychological mechanism of self-control, which operates internally within a person's soul and reminds a human being about his or her moral and ethical code of conduct in a collective. In Russian, having conscience is considered as a positive fact, and its absence - as a negative one.

Language objectification of this notion in the Russian conceptual sphere involves lexemes sovest', sovestno, sovestlivost', sovestlivyi, bessovestnyi, as well as units nelovko, gor'kii razlad s samim soboi, sila serdtsa svoego [13]. English conceptual sphere includes: the conscience, is ashamed, conscientious, unscrupulous (not unscrupulous), awkwardly, bitter dissonance with itself, force of heart.

Sometimes, a person may not hear a voice of its conscience (ubayukat' sovest'/to lull conscience asleep), preferring some profit to moral and ethical values [13]:

“... naidem nechto spasitel'noe, chto ubayukivaet nashu sovest' $i$ ne pozvolit postupit' chestno" / "...we will find some salvation lulling our conscience asleep and not allowing us to act honestly" (V. Shukshin);

"...shall do it and I shall comfort the conscience" (F.S. Fitzgerald).

In the Russian language, sovest'/conscience is often characterized as nespokoinaya, bol'naya, nezazhivayushchaya. In the English language, these attributes carry the following emotive senses: anxiety, grievance, doubt, which are considered to have dysphoric nature and emotional coloring. The concept is evaluated positively in both national cultures. 


\subsection{Concept dobro/good}

The concept dobro/good is the principal notion of evaluation within the category of ethics and morality, which defines a moral ideal aimed at creating a public good for everyone. In both languages, zlo/evil is a conceptual opposite to dobro/good. These concepts are evenly represented in both cultures and express fundamental attitudes of the peoples' moral consciousness, i.e. good is a norm, whereas evil is irregularity, destructive behavior leading to dissociation and death.

National conceptual spheres are always focused on a moral good, which is accomplished with direct participation of a human's inner world - consciousness and will [13]. Language representation of the concept implies common nature of moral and ethical norms in both linguistic worldviews.

The sphere of the concept in Russian includes a relative adjective chelovecheskii and qualitative adjectives umnyi, chelovechnyi, khoroshii, bol'shoi, sil'nyi, moshchnyi, mudryi, prostoi, chistyi, chestnyi, svetlyi, beskorystnyi, krasivyi, velikodushnyi [13]; the conceptual sphere in English covers the following adjectives: clever, human, good, large, strong, powerful, wise, idle time, net, honest, light, disinterested, beautiful, magnanimous.

Thus, the conceptual field of the key concept добро / good within the conceptual sphere of the Russian and English languages is defined by the semes with positive connotation: warm-heartedness; compassion; mercy; self-sacrifice; selflessness; kindheartedness; responsibility; sensitiveness; forwardness, honesty, openness, sincerity.

\subsection{Concept pravda/truth}

The concept pravda/truth implicates some perfect order of human existence that must be followed by everyone in order to achieve absolute harmony. From this perspective, its meaning matches the content of the concept spravedlivost'/righteousness: 'nado zhit' po pravde'/you must live truthfully or 'pravda vostorzhestvuet'/the truth will triumph.

Search for truth is primarily typical for the Russian mentality, and in the Russian linguistic worldview, the concept represents the supreme authority passing its own sentence [14].

Another meaning of the concept stands for correspondence between a person's assumptions and objective state of affairs. Here, the concept is common for both Russian and English mentality. To tell the truth means not to lie, not to cheat, not to falsify a real-life picture of events. Correct understanding of the concept allows people to communicate within uniform rules, without misunderstandings, worries and misinterpretations.

\subsection{Concept krasota/beauty}

In national cultures, a notion of outer beauty is generally shifted onto the notion of inner beauty: krasota dushi/beauty of the soul, krasota serdtsa/beauty of the heart. Description of outer beauty often has a shade of irony in its meaning, whether the inner beauty of a person is truly valued.

The concept is represented in both linguistic worldviews while characterizing both external manifestations of the intrinsic human features and moral origins of a personality as well: "Bet was very beautiful with a new hairstyle" (E. Hemingway). 
Representation of each concept studied above in the cultural discourse is characterized by a particular nation-specific perspective, related to transformations of a person's associative and visual thinking and features of the concepts existing in the overall linguistic worldview of a people or personality. As a result, this determines a particular nature of forming and expressing main concepts, which are universal for the Russian and English conceptual spheres, in the linguistic worldview of a people, a single person, and society. The concepts contain a formula of general welfare based on the principles of good and justice [15].

\section{Conclusion}

We conducted the analysis of image components of universal concepts sovest'/conscience, dobro/good, pravda/truth, krasota/beauty. Observing mental peculiarities of the concepts representation lets us conclude that specific images of conscience, good, truth and beauty are numerous and highly frequent in the Russian and English linguistic worldviews. The concepts are ethno-culturally significant both for Russian and English, becoming personification of an ideal world.

In conclusion, it should be noted that conceptual spheres of Russian and English are not always identical due to the differences in cultural and historical experience and heritage. The key concepts representation follows the rules of naming, whether reflection of a national identity in the universal concepts is defined by their internal form and external associative bonds. Different outlooks come from the peculiarities of national and cultural background of each people.

\section{References}

1. G.K. Harrison, Mentality, in Normative Reasons and Theism. Palgrave Frontiers in Philosophy of Religion (Palgrave Macmillan, Cham, 2018).

https://doi.org/10.1007/978-3-319-90796-3_3

2. C. Kertcher, O. Turin, Postdigit Sci Educ 2, 581-587 (2020). https://doi.org/10.1007/s42438-020-00175-8

3. Y. Yang, Theoretical Framework for Studying Social Mentality, in Y. Yang (ed), Social Mentality in Contemporary China. Research Series on the Chinese Dream and China's Development Path (Springer, Singapore, 2019). https://doi.org/10.1007/978-981-13-7812-6_1

4. M. Krzysztofik, J Relig Health (2020). https://doi.org/10.1007/s10943-020-01056-x

5. Y. Wu, Y. Yang, The "Mutual Construction" of Society and Individual in the Formation Process of Social Mentality, in Y. Yang (ed), Social Mentality in Contemporary China. Research Series on the Chinese Dream and China's Development Path (Springer, Singapore, 2019). https://doi.org/10.1007/978-981-13-7812-6_2

6. D.B. Rice, N. Reed, Curr Psychol (2021). https://doi.org/10.1007/s12144-021-01349-8

7. J. Husa, Constitutional Mentality, in P. Letto-Vanamo, D. Tamm, B. Gram Mortensen (eds), Nordic Law in European Context. Ius Gentium: Comparative Perspectives on Law and Justice, 73 (Springer, Cham, 2019). https://doi.org/10.1007/978-3-030-03006-3_3

8. L.A. Mishina, et al., Int J App Ling English Liter, 5(5), 153-157 (2016) 
9. I.I. Klimova, G.V. Klimova, S.A. Dubinka, XLinguae, 12(1), 207-218 (2019)

10. N.A. Kozlovtseva, N.N. Tolstova, Bakhtiniana, 14(1), 82-113 (2019)

11. E.V. Uryson, Arkhaicheskie predstavleniya v russkoi yazykovoi kartine mira [Archaic Perceptions in Russian Linguistic Worldview], Doct. thesis in Philology (Moscow, 1997)

12. I.S. Kon, Slovar etiki [Dictionary of Ethics] (Moscow, 1983)

13. T.N. Dolotova, Semanticheskoe pole emotsionalnosti i otsenochnosti i ego realizatsiya v zhurnalistike V.M. Shukshina [Semantic Field of Emotionality and Evaluativity and Its Implementation in Journalism by V.M. Shukshin] $\mathrm{PhD}$ thesis in Philology (Stavropol, 2003)

14. E.E. Smirnova, Semantika ponyatii ISTINA i FAKT v russkom yazykovom soznanii i ikh yazykovaya obyektivatsiya $\mathrm{v}$ sovremennom russkoyazychnom yazyke [Semantics of the concepts TRUTH and FACT in Russian Linguistic Consciousness and Their Language Objectification in Modern Russian Speaking] PhD thesis in Philology (Nizhny Novgorod, 2016)

15. Kh.Z. Khajmuradova, Lingua-Universum J, 3, 45-53 (2010) 